\title{
GOTONG ROYONG SAAT PANDEMI: KETEPATAN BANTUAN SOSIAL BAGI TERDAMPAK
}

\author{
Asmuni \\ Progam Studi Ilmu Administrasi Negara \\ Sekolah Tinggi Ilmu Administrasi Pembangunan Jember \\ *Email: Asmuni@gmail.com
}

\begin{abstract}
ABSTRAK
Warga yang membutuhkan bantuan untuk kebutuhan pokok mendesak adalah warga yang miskin. Menurut Data Susenas (BPS) Maret 2019 (sebelum Covid-19), ada sekitar 34\% warga yang berada di bawah garis kemiskinan hingga yang berada sedikit di atasnya (warga rentan miskin). Karena Covid-19, warga yang rentan miskin itu sekarang diperkirakan sudah masuk ke dalam kelompok miskin.

Sampai sekarang ada $21 \%$ warga yang mengaku sudah mendapat bantuan sosial dari pemerintah. Masih ada sekitar $13 \%$ yang belum mendapat bantuan tersebut. Sebanyak $87 \%$ warga yang sudah mendapat bantuan pun menyatakan bahwa bantuan tersebut hanya cukup untuk dua minggu atau kurang. Bantuan sosial dinilai belum mencapai sasaran karena

banyak yang membutuhkan mendesak tidak dapat, dan ada juga yang seharusnya tidak dapat malah dapat bantuan. Masih banyak warga bahkan belum tahu bagaimana mendaftar agar dapat bantuan. Berharap petugas datang ke warga yang berhak untuk mendaftar mereka. Karena diperkirakan pandemi ini belum berakhir cepat maka melanjutkan bantuan, menambah jumlah warga yang harus dibantu, dan memperbaiki mekanisme bantuannya, merupakan agenda bantuan sosial mendesak yang harus dilakukan pemerintah. Kata Kunci: Pemerintah, Bantuan, Covid-19
\end{abstract}




\section{Analisis Situasi}

Masa pandemi Covid-19 yang melanda dunia termasuk Indonesia telah membuat semua bidang kehidupan terdampak. Meskipun diawal pandemi, ada beberapa pihak yang menyangsikan tentang pandemi ini, namun pada akhimya semua pihak merasakan bahwa era pandemi ini telah ada dan berdampak secara langsung atau tidak langsung.

Bantuan sosial adalah pemberian bantuan dari Pemerintah Daerah kepada individu, keluarga, kelompok dan/atau masyarakat. Sifat bantuan ini, tidak secara terus menerus dan selektif. Bantuan ini berupa uang atau barang yang pemberiannya disesuaikan dengan kemampuan keuangan daerah. Tujuannya untuk menunjang pencapaian sasaran program dan kegiatan pemerintah daerah dengan memperhatikan asas keadilan, kepatutan, rasionalitas dan manfaat untuk masyarakat. Jaminan sosial adalah salah satu bentuk perlindungan sosial yang diselenggarakan oleh negara guna menjamin warga negaranya untuk memenuhi kebutuhan hidup dasar yang layak. Jaminan ini tercantum pada Undang-undang Nomor 40 tahun 2004 tentang Sistem Jaminan Sosial Nasional. Utamanya merupakan sebuah bidang kesejahteraan sosial yang memperhatikan perlindungan sosial yang di dalamnya termasuk kemiskinan, usia lanjut, kecacatan, pengangguran, keluarga dan anakanak. Hubungan bantuan sosial dengan jaminan sosial sangat berkaitan karena sangat mempengaruhi laju pertumbuhan penduduk di Indonesia. Salah satu penyebabnya peningkatan penduduk yang menyandang kecacatan yang diakibatkan dari ekonomi yang tidak memadai sehingga membuat para penyandang cacat berat menjadi bingung bagaimana bertahan hidup.

Situasi tersebut membuat kehidupan tidak berjalan normal. Hal yang paling dirasakan adalah adanya pembatasan sosial, dimana setiap orang dibatasi untuk kontak erat dengan orang lain. Bagi masyarakat Indonesia, kehidupan yang menutup diri, membatasi diri adalah hal yang berat untuk dilakukan. Mengingat bertemu dan 
membangun keakraban adalah modal sosial bagi sebagian besar masyarakat Indonesia.

Maka dengan mudah dijumpai, pembatasan sosial tersebut selalu dilanggar baik secara terangterangan atau dengan mensiasati. Secara umum, dapat dilihat misalnya pada daerah-daerah pinggiran melanggar batasan sosial terlihat lebih nampak. Sementara itu, di daerah sentral seperti perkotaan atau daerah urban melanggar batasan sosial dilakukan secara samar. Biasanya secara formalitas seperti anjuran-anjuran pembatasan sosial ditulis. Dari panggung depan terlihat ada batasan sosial tetapi di panggung belakang sesungguhnya abai terhadap batasan sosial.

Sehingga bukan menjadi hal aneh, jika dapat dari hari ke hari jumlah orang yang terjangkit Covid 19 terus bertambah. Selain, karena virus ini sangat berat dikendalikan dan mudah menular, perilaku dari sebagian masyarkat yang abai terhadap pembatasan sosial menjadi pemicu untuk semakin mudahnya pandemi ini menyebar.
Setelah

pernerintah rnengurnurnkan kasus pertarna warga negara terjangkit virus Covid 19 rnaka secara resrni Indonesia rnernasuki fase pandemic. Untuk rnenanggulangi keadaan tersebut pada pertengah bulan Maret 2020 sarnpai sekarang, pernerintah rnernutuskn berbagai kebijakan untuk rnenghadapi serta rnengatasi pandemic COVID-19, diantaranya; pertarna berdiarn diri di rurnah (Stay at Horne); Pernbatasan Sosial (Social Distancing); (Pernbatasan Fisik (Physical Distancing); Penggunaan Alat Pelindung Diri (Masker); Menjaga Kebersihan Diri (Cuci Tangan); (Bekerja dan Belajar di rurnah (Work/Study From Horne); Menunda sernua kegiatan yang rnengurnpulkan orang banyak; Pernbatasan Sosial Berskala Besar (PSBB) terbatas. Lalu juga rnuncul kebijakan New Normal. Dan sarnpai saat ini, selalu ditekankan adanya pengunaan protokol kesehatan dalarn setiap kegiatan. Karena tidak rnernungkinan seorang warga negara tetap berdiarn diri tanpa rnelakukan aktivitas ekonorni dan sosial. 
Untuk rnengatasi persoalan yang rnuncul, selain perlakuan kebijakan kesehatan bagi yang terdarnpak langsung. Pernerintah juga rnelakukan tindakan penanggulangan dengan sistern bantuan sosial sebagai bagian dari sistern jarninan sosial.

Bantuan sosial sosial Kernenterian Sosial digunakan untuk bantuna bagi rnasyarakat yang rnernbutuhkan, juga dipastikan rnernberikan darnpak baik kepada berbagai sektor. Daerah pingiran rnerupakan sasaran utarna dari probrarn bantuan sosial tersebut. Sektor pertanian dan perikanan adalah dua bidang utarna yang diprioritaskan, sebagai contoh penyaluran beras dan sernbako dalarn program keluarga harapan (PKH) untuk 10 juta keluarga penerirna rnanfaat (KPM) dapat rnernbantu Bulog untuk rnendistribusikan beras. Dengan dernikian, penyerapan hasil panen dari petani bisa berjalan lancar $[1\}$. Di lapangan penerirna rnanfaat ini tidak sernuanya sadar bahwa bantuan rnerupakan bagian Jaringan
Pengarnanan Sosial (JPS) terkait panderni.

Secara sederhana, program JPS, rnenjadi dua jenis yaitu bantuan sosial reguler dan non reguler. Pertarna, bantuan sosial reguler yaitu berupa pemberian Program Keluarga Harapan (PKH) dan Program Sembako. Dalam menghadapi pandemi COVID-19, pemerintah melalui Menteri Sosial telah mengambil kebijakan bahwa untuk program $\mathrm{PKH}$ akan diperluas menjadi 10 juta KPM (Keluarga Penerima Manfaat) yang dapat dicairkan setiap bulan [2\}. Hal tersebut dilakukan dengan tujuan untuk mengantisipasi krisis sosial dan ekonomi akibat pandemi COVID-19. Selain PKH, Kementerian Sosial juga menaikkan penerima manfaat program sembako yang awalnya 15,2 juta KPM kini menjadi 20 juta KPM dengan indeks RP 200.000 per bulan/per KPM.Kedua, bantuan sosial nonreguler bagi warga yang terdampak pandemi

COVID-19 yang belum tercover dalam bantuan rutin kepada penerima manfaat. 
Kehadiran bantuan non-reguler sebenamya merupakan wujud implementasi dari keputusan menteri sosial tahun 2020. Sebab, secara sosial dan ekonomi, pandemi Covid 19 telah meruntuhkan sendi ekonomi dam sosial meskipun orang atau keluarga tidak terjangkit virus Covid 19. Bantuan ini terdiri dari dua jenis yaitu bantuan sembako dan bantuan sosial tunai. Bantuan tersebut, khususnya sembako ditujukan bagi warga yang tercatat di Data Terpadu Kesejahteraan Sosial (DTKS). Secara teknis, penggunaan data terpadu ini, bersifat bottom- up [4] yang prosesnya dilakukan atas usulan dari leading sector yang paling bawah. Diterjemahkan sebagai usulan dari tingkat Rukun Tetangga (RT) ke Rukun Warga (RW) yang kemudian ditindaklanjuti oleh Desa/kelurahan untuk menyerahkan data tertulis kepada pemerintah daerah Kabupaten/ Kota melalui Dinas Sosial. Adanya data yang tidak tercatat dengan baik ditambah kemunculan kelompok-kelompok masyarakat miskin atau hampir miskin membuat data terpadu kesejaterana ini sangat cair dan fluktuatif.

Selain itu, bantuan non-reguler juga diberikan Kementerian Sosial dalam bentuk Bantuan Sosial Tunai kepada warga masyarakat terdampak di luar Bantuan ini ditujukan kepada masyarakat yang terdampak pandemi COVID-19, namun bukan penerima program reguler seperti Program Keluarga Harapan (PKH) dan Bantuan Pangan Non Tunai (BPNT). Proses yang panjang dan ketidaksiapan aparat ditingkat pelaksana paling bawah membuat penerima bantuan ini lemah dalam verifikasi data. Disamping itu, ketidak jelasan atau adanya distorsi informasi terkait bantuan sosial ini akibat level informasi yang berjenjang menyebabkan adanya kecemburuan sosial dilevel arus bawah.

Menurut ketentuan, Bantuan Sosial Tunai dilakukan dengan memberikan uang tunai sebesar 600 ribu per KK per bulan selama 3 bulan dengan target mencapai 9 juta KK. Sembilan juta KK ini didapatkan dari daerah tingkat 2, 
yaitu Kabupaten dan Kota. Jadi, dalam hal ini keleluasaan diberikan kepada Kabupaten atau Kota untuk memberikan data terkait keluarga yang benar benar terdampak secara langsung akibat pandemi Covid-19.

Adanya bantuan ini, diharapkan menjadi penopang sementara bagi kelompok masyarakat yang rentan dan sangat rentan secara ekonomi untuk mampu bertahan dalam ketidakpastian fase pandemi Covid-19 yang belum diketahui ujung berakhimya.

\section{Landasan Teori}

Pengelolaan Bantuan Sosial Dana adalah uang yang disediakan untuk suatu keperluan (Ardiyos, 2005). Menurut Ardiyos (2005), dana dapat didefinisikan sebagai uang, surat berharga, serta harta lainnya yang sengaja disisihkan bagi suatu tujuan tertentu yang telah ditetapkan. Kasmir (2008) mengemukakan bahwa: a. Dana dianggap sebagai kas b. Dana dianggap sebagai uang yang disimpan di bank dalam bentuk giro atau tabungan c. Dana dianggap sebagai modal kerja d. Dana dianggap sebagai seluruh aktiva yang dimiliki perusahaan e. Dana dianggap sebagai aktiva yang memiliki sifat sama dengan kas. Pengelolaan bantuan sosial didefinisikan sebagai upaya mengatur dari merencanakan sampai menyalurkan pemberian bantuan berupa uang/barang dari pemerintah daerah kepada individu, keluarga, kelompok dan/atau masyarakat yang sifatnya tidak secara terus menerus dan selektif yang bertujuan untuk melindungi dari kemungkinan terjadinya resiko sosial (Indonesia, 2012). Resiko sosial yang dimaksud ialah suatu kejadian atau peristiwa yang dapat menimbulkan potensi terjadinya kerentanan sosial yang ditanggung oleh individu, keluarga, kelompok dan/atau masyarakat sebagai dampak krisis sosial, krisis ekonomi, krisis politik, fenomena alam dan bencana alam yang jika tidak diberikan dana bantuan sosial akan semakin terputuk dan tidak dapat hidup dalam kondisi wajar (Indonesia, 2012). Dalam Dokumen Deskripsi dan Analisis APBD 2014 yang diterbitkan oleh Kementrian Keuangan Republik Indonesia, 
bantuan sosial didefinisikan sebagai 20 pemberian bantuan yang sifatnya tidak secara terus menerus dan selektif dalam bentuk uang/barang kepada masyarakat atau organisasi profesi yang bertujuan untuk kepentingan umum (Keuangan, 2014). Peraturan Menteri Keuangan Republik Indonesia No. 81 Tahun 2012 tentang belanja bantuan sosial pada kementrian negara/Lembaga mendefiniskan belanja bantuan sosila sebagai pengeluaran berupa transfer uang, barang dan jasa yang diberikan oleh pemerintah pusat/daerah kepada masyarakat guna melindungi masyarakat dari kemungkinan terjadinya risiko sosial, meningkatkan kemampuan ekonomi dan/atau kesejahteraan masyarakat. Di dalam Peraturan Menteri Pertanian Republik Indonesia No. 137 tahun 2014 tentang pengelolaan belnaja bantuan sosial kementrian pertanian tahun anggaran 2015, didefinisikan bahwa dana belanja bantuan sosial adalah penyaluran atau transfer uang kepada kelompok/masyarakat pertanian yang mengalami risiko sosial keterbatasan modal sehingga mampu mengakses pada Lembaga permodalan secara mandiri. Berdasarkan beberapa pengertian terkait dengan dana dan bantuan sosial yang telah dijelaskan diatas, maka dapat diperoleh penjelasan bahwa pengelolaan dana bantuan sosial dapat didefinisikan sebagai sejumlah uang yang dianggarkan didalam APBN/APBD oleh pemerintah pusat/daerah yang peruntukannya ialah sebagai bantuan berupa uang/barang kepada individu, keluarga, kelompok dan/atau masyarakt yang sifatnya tidak secara terus menerus dan seletif yang bertujuan untuk melindungi dari kemungkinan terjadinya risiko sosial. Dalam rangka pengelolaan dana pertanggungjawaban keuangan negara yang ditetapkan dalam APBN dan APBD, sehingga diperlukan suatu kaidah-kaiah hukum administrasi keuangan negara (Soeriaarmadja, 2010). Oleh karena itu, 21 segala hal yang berkaitan dengan pengelolaan dana bantuan sosial diatur di dalam peraturan Menteri dalam negeri yang telah mengalami beberapa kali perubahan. 2.1.5 Belanja Bantuan Sosial 1. Definisi Belanja Bantuan Sosial 
Komite Standar Akuntansi Pemerintah (2010) dalam Buletin Teknis Nomor 10 tentang Pedoman Akuntansi Belanja Bantuan Sosial mendefinisikan belanja bantuan sosial sebagai transfer uang atau barang yang diberikan oleh pemerintah pusat/daerah kepada masyarakat guna melindungi dari kemungkinan terjadinya risiko sosial. Transfer uang/barang/jasa tersebut memiliki ketentuan sebagai berikut: a. Belanja bantuan sosial dapat langsung diberikan kepada anggota masyarakat dan/atau lembaga kemasyarakatan termasuk di dalamnya bantuan untuk lembaga non pemerintah bidang pendidikan dan keagamaan. b. Belanja bantuan sosial bersifat sementara atau berkelanjutan. c. Belanja bantuan sosial ditujukan untuk mendanai kegiatan rehabilitasi sosial, perlindungan sosial, jaminan sosial, pemberdayaan sosial, penanggulangan kemiskinan dan penanggulangan bencana. d. Belanja bantuan sosial bertujuan untuk meningkatkan taraf kesejahteraan, kualitas, kelangsungan hidup, dan memulihkan fungsi sosial dalam rangka mencapai kemandirian sehingga terlepas dari risiko sosial. e. Belanja bantuan sosial diberikan dalam bentuk: bantuan langsung, penyediaan aksesibilitas, dan/atau penguatan kelembagaan. Terdapat sedikit tambahan definisi sebagaimana termuat dalam Peraturan Menteri Keuangan Nomor 81/PMK.05/2012 tentang Belanja Bantuan Sosial pada Kementerian/Lembaga dan Peraturan Menteri Keuangan Nomor 214/PMK.05/2012 tentang Bagan Akun Standar. Dalam kedua Peraturan Menteri Keuangan tersebut dinyatakan belanja bantuan sosial adalah pengeluaran berupa transfer uang, barang atau jasa yang diberikan oleh pemerintah (pusat/daerah) kepada masyarakat guna melindungi masyarakat dari kemungkinan terjadinya risiko sosial, meningkatkan kemampuan ekonomi 22 dan/atau kesejahteraan masyarakat. Belanja bantuan sosial dapat berupa pemberian uang, barang, maupun jasa, dengan penjelasan sebagai berikut: a. Pemberian dalam bentuk uang ditujukan kepada penerima bantuan 
sosial yang telah memenuhi kriteria. Bantuan uang ini dimaksudkan bukan untuk dapat ditarik kembali melalui mekanisme dana bergulir, bukan berupa penguatan modal masyarakat PNPM Mandiri, dan bukan pemberian kepada partai politik. b. Pemberian dalam bentuk barang ditujukan kepada penerima bantuan sosial yang telah memenuhi kriteria. Barang yang diberikan dapat berupa barang habis pakai maupun berupa aset tetap, berasal dari hasil membeli atau hasil memproduksi sendiri. Bantuan barang tersebut juga bukan untuk dipakai sendiri atau diberikan kepada instansi vertikal pemerintah yang bersangkutan, sehingga tidak menambah jumlah aset yang dimiliki oleh satuan kerja terkait atau instansi vertikal di bawahnya. c. Pemberian dalam bentuk jasa ditujukan kepada penerima bantuan sosial yang telah memenuhi kriteria. Bantuan jasa yang diberikan dapat berupa pelatihan atau mengirimkan orang untuk memberikan pelatihan. 2. Definisi Risiko Sosial Salah satu tujuan pemerintah mengalokasikan anggaran belanja bantuan sosial adalah untuk melindungi masyarakat dari kemungkinan terjadinya risiko sosial. International Monetary Fund (2014) menjelaskan bahwa risiko sosial adalah kejadian atau peristiwa yang dapat berdampak buruk pada kesejahteraan rumah tangga (masyarakat) yang disebabkan oleh bertambahnya beban permintaan atas sumber daya ataupun oleh berkurangnya pendapatan. Direktorat Jendral Anggaran Kementerian Keuangan Republik Indonesia (2014) dalam Postur APBN di Indonesia mendefinisikan risiko sosial sebagai kejadian atau peristiwa yang dapat menimbulkan potensi terjadinya kerentanan sosial yang ditanggung oleh individu, keluarga, kelompok dan/atau masyarakat sebagai dampak krisis sosial, krisis ekonomi, krisis politik, fenomena alam, dan bencana alam yang jika tidak diberikan belanja bantuan sosial akan semakin terpuruk dan tidak dapat hidup dalam kondisi wajar. World Bank (2003) dalam Holzmann et al (2003) menjelaskan bahwa karakteristik risiko berdasarkan 23 sumbernya dapat berasal dari kejadian alam (contohnya bencana banjir) ataupun 
dari hasil aktivitas manusia (contohnya inflasi yang berasal dari kebijakan ekonomi). Lebih jauh, Komite Standar Akuntansi Pemerintah (2010) menjabarkan keadaan yang memungkinkan timbulnya risiko sosial antara lain, namun tidak terbatas pada:

a. Wabah penyakit yang apabila tidak ditanggulangi maka akan meluas dan memberikan dampak yang memburuk kepada masyarakat.

b. Wabah kekeringan atau paceklik yang bila tidak ditanggulangi akan membuat petani/nelayan menjadi kehilangan penghasilan utamanya.

c. Cacat fisik dan/atau mental yang bila tidak dibantu tidak akan bisa hidup secara mandiri.

d. Penyakit kronis yang bila tidak dibantu tidak akan bisa hidup secara mandiri.

e. Usia lanjut yang bila tidak dibantu tidak akan bisa hidup secara mandiri.

f. Putus sekolah yang bila tidak dibantu akan semakin terpuruk dan tidak dapat hidup secara mandiri. g. Kemiskinan yang bila tidak dibantu akan semakin terpuruk dan tidak dapat hidup secara wajar.

h. Keterisolasian tempat tinggal karena kurangnya akses penghubung yang mempersulit perkembangan masyarakat di suatu daerah.

i. Bencana yang apabila tidak ditanggulangi akan mengancam dan mengganggu kehidupan dan penghidupan masyarakat. Asian

Development Bank (2001) menjabarkan tipe-tipe risiko yang rentan dihadapi masyarakat sebagai berikut: a. Risiko yang terkait dengan siklus hidup, misalnya kelaparan, penyakit, cacat, lanjut usia, dan kematian. b. Risiko yang terkait dengan kondisi ekonomi, misalnya hilangnya sumber penghasilan, pengangguran, pendapatan rendah, kenaikan harga kebutuhan pokok dan krisis ekonomi. c. Risiko yang terkait dengan lingkungan, misalnya kekeringan, banjir, gempa bumi, dan tanah longsor. d. Risiko yang terkait dengan kondisi 
sosial/kepemerintahan, misalnya kehilangan status sosial, kekerasan domestik, ketidakstabilan politik, dan korupsi. Risiko-risiko diatas dapat terjadi secara sendiri maupun bersamaan. Demikian pula risiko tersebut dapat mempengaruhi secara langsung kepada individu maupun kepada kelompok masyarakat yang pada akhirnya akan mempengaruhi individu. 24 3. Pengalokasian Anggaran Belanja Bantuan Sosial Pengalokasian anggaran belanja bantuan sosial dalam APBN mengacu pada ketentuan yang diatur dalam Peraturan Menteri Keuangan mengenai penyusunan dan penelaahan Rencana Kerja dan Anggaran Kementerian Negara/Lembaga (RKA-K/L). Anggaran belanja bantuan sosial disusun oleh kementerian negara/lembaga dengan memperhatikan: a. Tujuan penggunaan bantuan sosial, $b$. Pemberi bantuan sosial, c. Penerima bantuan sosial, dan d. Bentuk bantuan sosial yang disalurkan. Pengeluaran belanja bantuan sosial hanya dapat dilakukan untuk kegiatan yang ditujukan untuk: a.
Rehabilitasi sosial, yaitu upaya yang bertujuan untuk memulihkan dan mengembangkan kemampuan seseorang yang mengalami disfungsi sosial agar dapat melaksanakan fungsi sosialnya secara wajar; $b$. Perlindungan sosial, yaitu upaya yang bertujuan untuk mencegah dan menangani risiko dari guncangan dan kerentanan sosial seseorang, keluarga, kelompok, dan/atau masyarakat agar kelangsungan hidupnya dapat dipenuhi sesuai dengan kebutuhan dasar minimal; c. Pemberdayaan sosial, yaitu upaya yang diarahkan untuk menjadikan warga negara yang mengalami masalah sosial mempunyai daya sehingga mampu memenuhi kebutuhan dasarnya; d. Jaminan sosial, yaitu skema yang melembaga untuk menjamin seluruh rakyat agar dapat memenuhi kebutuhan dasar hidupnya yang layak; e. Penanggulangan kemiskinan, yaitu kebijakan, program, dan kegiatan yang dilakukan terhadap orang, keluarga, kelompok dan/atau masyarakat yang tidak mempunyai atau mempunyai sumber mata pencaharian dan tidak dapat 
memenuhi kebutuhan yang layak bagi kemanusiaan; dan $f$. Penanggulangan bencana, yaitu serangkaian upaya yang meliputi penetapan kebijakan pembangunan yang berisiko timbulnya bencana, kegiatan pencegahan bencana, tanggap darurat dan rehabilitasi. Bentuk bantuan sosial yang disalurkan dapat berupa uang, barang, dan/atau jasa. Khusus untuk bantuan dalam bentuk barang dan/atau jasa, tata cara pengadaannya harus mengacu pada peraturan perundang-undangan mengenai pengadaan barang/jasa pemerintah. Penganggaran belanja bantuan sosial hanya diperkenankan untuk kegiatan yang telah memenuhi seluruh 25 kriteria belanja bantuan sosial baik dari sisi pengertian, tujuan, persyaratan penerima, pemberi dan sifatnya. Penganggaran belanja ini meliputi seluruh biaya yang dikeluarkan untuk kegiatan terkait dengan penyelenggaraan bantuan sosial tersebut. Sebagai contoh, belanja bantuan sosial terkait dengan pengadaan barang yang dikonsumsi atau barang modal meliputi komponen biaya honor panitia pengadaan, biaya pembelian/pengadaan, biaya pengiriman/distribusi, dan pengeluaran lainnya hingga barang tersebut sampai di tangan penerima bantuan sosial. Penyusunan anggaran merupakan titik awal dalam proses penganggaran, sehingga kesalahan dalam penyusunan anggaran baik dari klasifikasi, peruntukan dan penerima akan mempengaruhi pelaksanaan dan pertanggungjawaban anggaran tersebut. Dalam PMK Nomor 143/PMK.02/2015 tentang Petunjuk Penyusunan dan Penelaahan Rencana Kerja dan Anggaran Kementerian Negara/Lembaga dan Pengesahan Daftar Isian Pelaksanaan Anggaran diatur ketentuan mengenai penerapan konsep nilai perolehan (full costing) untuk jenis belanja bantuan sosial. Suatu keluaran (output) yang dihasilkan kegiatan dalam rangka bantuan kepada lembaga pendidikan dan/atau peribadatan (yang berkontribusi pada kegiatan bantuan sosial), pengalokasian anggarannya dimasukkan ke dalam 2 jenis belanja yaitu Belanja Barang (termasuk 
biaya honorarium pelaksanaan kegiatan dengan kode akun 521213) dan Belanja Bantuan Sosial untuk menampung besaran alokasi bantuan yang diberikan.

Kebijakan Terkait Pengelolaan Dana Bantuan Sosial Persiapan merupakan tahap awal kegiatan setelah Kementerian Sosial menetapkan pagu program Sembako, wilayah kabupaten/kota dan mekanisme pelaksanaan, serta Bank Penyalur. 26 1. Koordinasi a. Koordinasi Di Tingkat Pemerintah Pusat Koordinasi di tingkat Pemerintah Pusat dilakukan antara Kementerian Sosial sebagai Pengguna Anggaran (PA) program Sembako dan Kementerian/ Lembaga $(\mathrm{K} / \mathrm{L})$ terkait melalui forum Tim Koordinasi Bansos Pangan Pusat dan dilaporkan/ dikonsultasikan kepada Tim Pengendali. Koordinasi dengan $\mathrm{K} / \mathrm{L}$ dilakukan untuk memperoleh masukan dan arahan terkait kebijakan pelaksanaan program. Selain itu, koordinasi dilakukan untuk memastikan dasar hukum, mekanisme dan tahapan pelaksanaan program, serta berbagai prosedur administrasi lainnya. b. Koordinasi di Tingkat Pemerintah Provinsi Pemerintah Provinsi melalui forum Tim Koordinasi Bansos Pangan Provinsi melakukan koordinasi secara berjenjang dengan Tim Koordinasi Bansos Pangan Kabupaten/Kota terkait seluruh tahap pengelolaan dan pelaksanaan program Sembako di Kabupaten/Kota, mulai dari dukungan pendanaan melalui APBD, koordinasi pagu dan data KPM, sosialisasi, penanganan pengaduan, pemantauan, dan dukungan lain yang diperlukan. c. Koordinasi di Tingkat Pemerintah Kabupaten/Kota Pemerintah Kabupaten/Kota melalui forum Tim Koordinasi Bansos Pangan Kabupaten/Kota melakukan koordinasi secara berjenjang dengan kecamatan dan desa/kelurahan untuk seluruh tahap pelaksanaan program, mulai dari persiapan pendanaan APBD dan/atau Dana Desa, verifikasi dan validasi data calon KPM dalam SIKS-NG menu BSP, proses registrasi/distribusi $\mathrm{KKS}$, pengecekan keberadaan KPM, edukasi dan sosialisasi, pemantauan, 
hingga penanganan pengaduan. 27

Pemerintah

Kabupaten/Kota

melakukan koordinasi dengan Bank

Penyalur untuk menyusun jadwal

registrasi $\mathrm{KPM} /$ distribusi $\mathrm{KKS}$ di masingmasing desa/kelurahan serta memastikan keterlibatan perangkat desa/aparatur kelurahan dalam proses tersebut. Pemerintah Kabupaten/Kota memberikan dukungan sarana dan prasarana, edukasi dan sosialisasi, kemudahan perizinan, pembebasan atau keringanan biaya perizinan serta fasilitas perpajakan kepada eWarong sesuai dengan ketentuan peraturan perundang-undangan. Pemerintah Kabupaten/Kota berkoordinasi dengan Bank Penyalur mengenai pemetaan lokasi dan pemilihan pedagang-pedagang bahan pangan untuk menjadi eWarong. Pelaksanaan program Sembako di tingkat Kabupaten/Kota dikoordinasikan oleh Tim Koordinasi Bansos Pangan Kabupaten/Kota. Pelaksanaan di tingkat Kecamatan dikoordinasikan oleh Tim Koordinasi Bansos Pangan Kecamatan. Pelaksanaan di tingkat desa/kelurahan didukung oleh perangkat desa/aparatur kelurahan setempat dan Pendamping Sosial Bansos Pangan 2. Penyiapan Data Keluarga Penerima Manfaat a. Penyiapan data KPM program Sembako dilaksanakan melalui aplikasi SIKS-NG menu BSP dan mengacu pada Penerima Manfaat. $b$.

Daftar Calon KPM program Sembako pada SIKSNG menu BSP sudah diberikan penanda untuk KPM yang merupakan penerima manfaat PKH KPM PKH diutamakan sebagai penerima manfaat program Sembako. c. Jumlah data calon KPM yang tersedia di SIKS-NG menu BSP idealnya sama dengan pagu program Sembako yang ditetapkan untuk setiap 28 kabupaten/kota. Jika jumlah data calon KPM pada SIKSNG menu BSP kurang dari pagu, maka daerah diminta untuk mengusulkan calon KPM untuk memenuhi pagu. Data usulan tersebut harus bersumber dari Data Terpadu Kesejahteraan Sosial. Jika jumlah data calon KPM pada SIKSNG menu BSP lebih besar dari pagu program Sembako, maka Kementerian Sosial akan melakukan 
penyesuaian jumlah calon KPM terhadap pagu yang telah ditetapkan. d. Pemerintah Kabupaten/Kota harus memeriksa data calon KPM pada SIKS-NG menu BSP, melakukan perubahan data sesuai kondisi terkini, serta melengkapi 7 (tujuh) variabel pembukaan rekening (KYC) pada SIKS-NG menu BSP. e. Perubahan data calon KPM dapat berupa penonaktifan calon KPM dari program, pengusulan calon KPM baru, dan perbaikan data Pengurus KPM. f. Perubahan data calon KPM dilakukan melalui musyawarah desa/kelurahan (musdes/muskel). g. Penonaktifan calon KPM dari program dilakukan jika calon KPM yang terdapat pada SIKS-NG menu BSP: 1. Meninggal dunia dan merupakan calon KPM beranggota tunggal/tidak ada anggota keluarga lain; 2. Tidak ditemukan keberadaannya dalam lingkup desa/kelurahan; 3. Tercatat ganda (2 kali atau lebih) pada SIKSNG menu BSP. Bagi KPM yang tercatat ganda (dua kali atau lebih) pada DPM program, maka salah satu data KPM dipertahankan, sementara sisanya diganti mengikuti mekanisme penggantian KPM. 4. Sudah mampu; 5. Menolak program; atau 6. Menjadi pekerja migran Indonesia sebelum melakukan aktivasi. 29 h. Pengusulan calon KPM baru adalah untuk menggantikan calon KPM yang dinonaktifkan dan untuk memenuhi pagu program yang ditetapkan untuk setiap kabupaten/kota. i. Keluarga yang diusulkan menjadi calon KPM program Sembako adalah keluarga yang terdapat dalam Data Terpadu Kesejahteraan Sosial. j. Pemerintah Kabupaten/Kota memastikan kelengkapan pengisian variabel KYC untuk setiap calon KPM pada SIKS-NG menu BSP. Variabel pembukaan rekening mengacu pada Penerima Manfaat. k. Untuk daerah yang tidak melakukan verifikasi dan validasi data, maka data KPM yang akan digunakan adalah data yang tersedia di dalam Data Terpadu Kesejahteraan Sosial yang dikelola oleh Kementerian Sosial. 3. Penyaluran Dana Bantuan Proses penyaluran dana bantuan program Sembako dilaksanakan sebagai berikut: a. Proses penyaluran dana bantuan program Sembako 
dilaksanakan oleh Bank Penyalur tanpa pengenaan biaya. b. Proses penyaluran dilakukan dengan memindahbukukan dana bantuan program Sembako dari rekening Kementerian Sosial (KPA) di Bank Penyalur ke rekening bantuan pangan/ sub-akun uang elektronik KPM. c. Pemindahbukuan dana bantuan program Sembako ke rekening/sub-akun elektronik KPM dilakukan paling lama 30 hari kalender sejak dana tersebut ditransfer dari Kas Negara ke rekening Kementerian Sosial di Bank Penyalur. 30 d. Penyaluran dana bantuan program Sembako ke dalam rekening bantuan pangan/subakun uang elektronik KPM dilakukan setiap bulan, paling lambat tanggal 10 (sepuluh) bulan berjalan; e. Proses penyaluran dana bantuan program Sembako dilakukan sesuai dengan ketentuan peraturan perundang-undangan mengenai Belanja Bansos yang ditetapkan oleh Menteri yang menyelenggarakan urusan pemerintahan di bidang keuangan.

Berangkat dari pemahaman analisis masalah dan latarbekang masalah, tulisan ini merasa penting untuk menjelaskan referensi yang dipakai terutama terkait landasan teori yang digunakan. Berikut beberapa teori yang digunakan: Suharto mendefinisikan perlindungan sosial sebagai segala inisiatif baik yang dilakukan pemerintah, swasta, atau masyarakat untuk mewujudkan transfer pendapatan atau konsumsi pada penduduk miskin, melindungi kelompok rentan terhadap risiko penghidupan, serta meningkatkan status sosial kelompok-kelompok yang terpinggirkan.

Di Indonesia, pelaksanaan sistem perlindungan sosial telah dilakukan melalui berbagai program dan telah berjalan lama. Programprogram perlindungan sosial tersebut telah dilaksanakan sejak masa pemerintahan orde baru. Meski begitu, program-program tersebut belum dirancang secara eksplisit dibawah sebuah sistem perlindungan sosial. Sistem perlindungan sosial Indonesia diarahkan untuk membantu mewujudkan pembangunan yang 
lebih merata dan berkeadilan. Hingga kini, sistem perlindungan sosial di Indonesia telah dituliskan dalam berbagai rencana dan dokumen strategis seperti Master Plan Percepatan Pengurangan (MP3KI) serta Social Protection Floor (Landasan Perlindungan Sosial). Rancangan dari berbagai pihak tersebut penting untuk diselaraskan dengan dokumen perencanaan pemerintah dalam sebuahkerangka yang menjadi landasan pelaksanaan program selama periode pembangunan yang akan berjalan.

Beberapa kajian dan referensi tentang jaminan sosial juga disampaikan oleh beberapa ahli lian. Motivasi mendasar bagi jaminan sosial adalah untuk mengasuransikan terhadap kejadian buruk berupa kematian atau terlalu tua untuk bekerja dengan memberikan penghasilan dukungan bagi mereka yang sudah pensiun atau yang selamat dari pekerja yang telah meninggal. Tujuan ini mengarah pada masalah bahaya moral alami: pekerja dapat pensiun dini atau hilang penghasilan sehingga menjadi rentan terhadap kemiskinan $[6\}$. Sementara itu Attanasio dan Rohwedder [7] juga berpendapat bahwa jaminan sosial harus melingkupi mereka yang rentan, biasanya merujuk kepada para orang yang tidak bekerja, berhenti kerja (pensiuan) baik dalam keadaan normal maupun dikarena sebab lain sebelum waktunya.

Sedikit lebih detail Hyman [8] mengarisbawahi asuransi sosial sebgai bagian dari jaminan sosial, dimana asuransi sosila merupaka bentuk asuransi publik yang memberikan perlindungan terhadap risiko ekonomi. Partisipasi dalam asuransi sosial adalah wajib. Dalam arti, wajib secara kewajiban untuk terlibat dalam sumbangan dan wajib mengikuti (terdaftar) sebagai peserta. Partisipasi tersebut bisa berupa dorongan dari atas atau berupa kesadaran dari bawah (grass root).

Jaminan sosial adalah mekanisme penghimpunan dana wajib dari iuran untuk memberikan 
perlindungan atas risiko sosial ekonomi yang diderita peserta dan / atau anggota keluarganya [9]. Sementara itu, pendapat lebih dalam tentang jaminan sosial termasuk memastikan pendapatan minimum, pendekatan asuransi sosial, bantuan untuk orang-orang dengan keadaan yang sangat sulit rnelalui pengernbangan kapasitas yang dijarnin sendiri untuk penduduk, subsidi negara, sistern asuransi dan kontribusi sukarela dari organisasi dan individu.

Pada akhimya jarninan sosial setidak harus rnengandung ernpat hal [11]. Pertama, berfisat universal: kebijakan jarninan sosial harus ditujukan untuk rnencakup seluruh populasi usia sernua orang untuk rnernastikan hak kesejahteraan. kedua, keadilan: Jarninan sosial yang diterjernahkan dalarn polis asuransi sosial harus rnernastikan bahwa sernua kelornpok dapat berpartisipasi dan rnendapatkan keuntungan yang sama. Ketiga, publisitas dan transparansi: Jarninan sosial yang diterjernahkan dalarn polis asuransi sosial polis harus rnernastikan publisitas dan transparansi kebijakan, peraturan, hak dan tanggung jawab entitas yang diatur oleh polis. Keempat, keberlanjutan finansial: pengernbangan asuransi sosial harus rnernastikan keberlanjutan dana asuransi sosial. Kelima, peran Pernerintah: rnernastikan sernua warga negara dapat berpartisipasi dalarn sistern asuransi sosial. Harus ada solusi yang tepat untuk setiap kelornpok sasaran tertentu

\section{Identifikasi dan Perumusan}

\section{Masalah}

Dari uraian di atas, rnuncul pertanyaan sebagai berikut:

a. Bagairnana rnernbangun kesadaran tentang tanggung jawab sosial bagi rnasyarakat terdarnpak?

b. Bagairnana rnengunakan bantuan sosial secara efektif, sesuai kebutuhan dan tujuan bantuan?

\section{Tujuan Kegiatan}

Kegiatan pengabdian pada rnasyarakat ini bertujuan untuk:

a. Mernberikan pernaharnan kepada segrnen terdarnpak tentang rnakna bantuan sosial 
b. Bantuan sosial dirnanfaatkan secara efektifbagi penerirna rnanfaat

\section{Manfaat Kegiatan}

Adapun manfaat yang dapat diperoleh setelah berlangsungnya kegiatan sosialisasi ini adalah:

a. Penerima Manfaat memiliki pemahaman tentang jaminan sosial dan bantuan sosial

b. Penerima manfaat, mampu menggunakan peruntukan bantuan secara tepat sasaran.

\section{Kerangka Pemecahan Masalah}

Berdasarkan kondisi faktual dari analisis situasi saat pengabdian masyarakat, rujukan teori yang digunakan, rumusan masalah yang diajukan, tujuan dan manfaat dari tulisan pengabdian ini maka kerangkah pemecahan masalah diuraikan sebagai berikut. Masalah utama adalah dua hal; pertama, membangun kesadaran tentang tanggung jawab sosial bagi masyarakat terdampak. Kedua, pengunaan kebutuhan dan tujuan bantuan. bantuan sosial secara efektif, sesuai
Bahwa tidak semua kelompok masyarkat menenma bantuan sosial. Meskipun bisa dilihat bahwa masyarakat yang pantas menerima bantuan sosial sesungguhnya lebih tinggi dari data faktual, hasil verifikasi lembaga yang mempunyai otoritas. Pada saat pandemi atau sebelum pandemi, isu terkait kreteria penerima bantuan sosial selalu menjadi persoalan. Sebelum pandemi masalah-masalah yang muncul tersentral pada kreteria penerima secara fisik seperti luas rumah, lantai rumah atau luas rumah yang tidak sesuai dengan kentetuan Kemensos tetapi sejatinya pendapatan masyarakat masih dibawah dua dolar perhari, misalnya. Namun begitu, hal tersebut bisa terselesaikan karena didata difokuskan kepada kelompokkelompok miskin dengan kretria khusus atas program nasisoanl "Program Keluarga Harapan". Pada masa pandemi, persoalan kreteria penerima bantuan sosial semakin rumit, karena banyak kelompok masyarakat yang sebelumnya 
berdaya, dalam beberapa hal menjadi kurang berdaya atau tidak berdaya.

\section{Khalayak Sasaran}

Program pengabdian ini, sejatihnya tidak menfokuskan pada evaluasi kepada kreteria penerima manfaat. Alasanya, selain kondisi pandemi yang masih tinggi tingkat penyebarannya, yang tidak memungkinkan untuk secara intens bersentuhan dengan banyak stakeholders. Alasan lain adalah pelaksanaan distribusi bantuan sosial telah berjalan. Fokus utama pengabdian ini adalah membangun kesadaran tentang bantuan sosial.

Kesadaran bantuan sosial bertumpuh pada ketegasan untuk memberikan bantuan atas skala prioritas pada siapa yang berhak menerima bantuan.

Kesadaran dari pelaksana bahwa bantuan sosial tidak berfisat personal dan impersonal menjadi prasyarat untuk mendata dan membagikan batuan sosial, baik tunai maupun non tunai.

Selain ketegasan dalam hal ketentuan dan pelaksanaan, hal yang tidak kalah penting adalah kesadaran dari masyarakat secara umum dan kelompok-kelompok penerima. Kesadaran makna bantuan sosial itu penting untuk menjaga ketepatan bantuan bagi terdampak. Yaitu kesadaran dari semua elemen masyarakat bahwa bantuan tersebut memang dikhususkan kepada mereka yang tidak mampu, dibawah garis kemiskinan atau terdampak Covid-19.

Kesadaran makna bantuan sosial bagi penerima bantuan sosial. Hal yang paling penting dalam bagi penerima manfaat adalah tidak ada penerima ganda untuk jenis bantuan yang berbeda. Pemantauan dan pendampingan kepada kelompok sasaran dalam pengabdian kali ini, menemukan bahwa penerima manfaat bantuan sosial merasa mempunyai hak untuk memperoleh jenis bantuan yang berbeda. Yaitu membedakan antara bantuan sosial reguler (merujuk pada bantuan sosial sebelum pandemi) dengan bantuan saat pandemi. Secara umum, bantuan untuk penerima bantuan reguler saat pandemi adalah dengan produk yang sama dengan sebelum pandemi 
tetapi ditambah dengan bantuan non tunai berupa sembako. Sementara bantuan sosial saat pandami merupakan listing baru atas dasar ketentuan kreteria penerima terdampak.

Munculnya kesadaran ini, adalah landasan untuk membangun solidaritas sosial bahwa masa pandemi adalah masa untuk tenggangrasa kepada semua pihak. Apalagi, bantuan sosial bukan bersumber pada pendanaan yang tidak terbatas. Seperti deketahui bersama bahwa dana untuk penanggulangan Covid 19 ini sebagian besar bersumber pada utang negara.

Atas dasar bahwa bantuan sosial berasal dari sumber yang terbatas dan sebagian yang lain tentunya dari pajak kelompok masyarakat yang lain sebagai sumber pemasukan negara, pada bagian kedua fokus kajian ini menyoroti ketepatan tujuan dan kegunaan bantuan sosial. Berdasarkan tujuan dan kebutuhan kelompok sasaran penerima bantuan sosial ini, dapat dilihat bahwa sebagai besar efektivitas kegunaan bantuan diperuntukkan pada pendidikan. Secara umum, hal tersebut masih dinilai sesuai tujuan karena bukti di lapangan, anggota keluarga penerima bantuan masih tetap menempuh pendidikan.

\section{Metode Kegiatan}

Kelompok sasaran dalam pengabdian ini adalah peneriama manfaat dari bantuan sosial yang tergabung dalam keluarga "Program Keluarga Harapan (PKH)" di Desa Jatimulyo Kecamatan Jenggawa Kabupaten Jember.

Kegiatan ini diawali dengan terlebih dahulu menyampaikan permohonan ijin kepada penanggung jawab wilayah, serta mengumpulkan khalayak sasaran untuk pelaksanaan kegiatan sosialisasi.

Materi : Gotong Royong Saat Pandemi: Ketepatan Bantuan Sosial Bagi Terdampak

Media : Makalah- PPT- ViewerInternet

Metode : Ceramah, dialog dengan penerima manfaat dengan prokokol kesehatan

Waktu : Pukul 10.00-11.30 WIB 


\section{Evaluasi Kegiatan}

Evaluasi

difokuskan pada keberhasilan

kelompok penenma manfaat untuk mengerti dan memahami tentang bantuan sosial, jamina sosial di Indonesia. Oleh sebab itu, setiap anggota kelompok sasaran menyampaikan pandanganya terkait bantuan sosial. Disamping itu, atas dasar telah menerima manfaat bantuan sosial, sejatinya mereka adalah kader untuk mencapaikan kepada penerima bantuan sosial barn bahwa keberhasilan bantuan sosial adalah ketika mereka secara mandiri telah berhasil untuk tidak menerima bantuan.

Dalam konteks pandemi Covid-19, para penenma bantuan sosial ini merupakan penyambung lidah dari pelaksana pengabdian yaitu duta penangulan pandemi Covid-19, minimal pada tingkat anggota rumah tangga. juga melakukan pendampingan kepada anggota kelompok mitra dalam hal mengungga produk mereka ke pasar online. Kedepan, perlu untuk melakukan mendampingan dalam hal melakukan transaksi online secara terus-menerus.

\section{Daftar Pustaka}

Keputusan Mensos No $54 / \mathrm{HUK} / 2020$ tentang

Pelaksanaan Bantuan Sosial Sembako dan Bantuan Sosial Tunai Dalam Penanganan Dampak COVID-19

Sekretariat Kabinet. (2020). Atasi Dampak Covid-19, Kemensos Berikan Bansos Reguler dan Nonreguler.

https://setkab.go.id/atasi dampak-covid-I9 kemensosberikan-bansos-reguler-dan non reguler

J Jonathan, Gruber. 2010. Public Finance and Public Policy. Massachusetts Institute of Technology Worth Publishers

Attanasio, Orazio P., and Susann Rohwedder. "Pension Wealth and Household Saving: Evidence from Pension Reforms in the United Kingdom." American Economic Review 93 
(5, December 2003): 1499-1521.

dalam Jonathan, Gruber. 2010.

Public Finance and Public

Policy. Massachusetts Institute

of Technology Worth

Publishers.

David N, Hyman. 2010. Public

Finance: A Contemporary

Application of Theory to

Policy, Tenth Edition. Copyright

2010 Cengage Leaming.

Undang-undang Nomor 40 tahun 2004 tentang Sistem Jaminan Sosial Nasional http://www.jkn.kemkes.go.id/ attachment/unduhan/UU\%20No. $\% 2040 \% 20$

David N, Hyman. 2010. Public Finance: A Contemporary Application of Theory to Policy, Tenth Edition. Copyright 2010 Cengage Leaming 